\title{
Uranium-series isotopes from Eemian lake deposits, Hollerup, Denmark
}

\author{
CARSTEN ISRAELSON, SVANTE BJÖRCK, CHRIS J. HAWKESWORTH \& NANNA NOE-NYGAARD
}

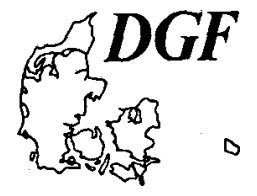

Israelson, C., Björck, S., Hawkesworth, C. J. \& Noe-Nygaard, N.: Uranium-series isotopes from Eemian lake deposits, Hollerup, Denmark. Bulletin Geological Society of Denmark, Vol. 44, pp. 173-179. Copenhagen 1998-02-28. 10.37570/bgsd-1998-44-11

We report the results of a U-series isotope study on Eemian lake sediments from Hollerup, western Denmark. The purpose is to examine the possibility of dating these, and similar, sediments with the ${ }^{238} \mathrm{U}-{ }^{230} \mathrm{Th}$ method. Two sedimentary facies were studied; carbonate-present, and virtually carbonate-free but organic-rich sediments. All carbonate-present sediments (5-95\%) have $\left({ }^{230} \mathrm{Th} /{ }^{38} \mathrm{U}\right)$ values higher than unity and relatively radiogenic $\left({ }^{230} \mathrm{Th} /{ }^{32} \mathrm{Th}\right)$ values between 2 and 6.5 , indicating postdeposition removal of $U$, probably by percolation of ground water. Carbonate-free sediments, but with high organic content $(40-60 \%)$ had $\left({ }^{230} \mathrm{Th} /{ }^{238} \mathrm{U}\right)$ values lower than 1 and 'model ages' between 89 and $199 \mathrm{ky}$. The large spread in ages and variation in U content for these sediment samples that were deposited over a much shorter time interval, indicate a complex postdeposit-ional migration pattern of $U$, probably involving several episodes of leaching and absorption of $U$ from ground water. Our results suggest that lake sediments, such as those found in Hollerup, are vulnerable to mobilization of $U$ and its decay products and care should be taken when interpreting U-series disequilibrium data from such sediments. Future studies will concentrate on sediments that have been more deeply buried and/or are less compacted and sealed from percolation of oxidized groundwater.

Keywords: Eemian, interglaciation, Hollerup, U-Th dating, sediments.

C. Israelson, S. Björck \& N. Noe-Nygaard, Geological Institute, University of Copenhagen, Øster Voldgade 10, DK-1350 Copenhagen K, Denmark. C. J. Hawkesworth, Department of Earth Sciences, The Open University, Milton Keynes, MK7 6AA, UK. 22 August 1997.

The Hollerup site (Figs 1-2) is a classic locality for studies of the Eemian environment in northern Europe and has been studied for almost 100 years (Hartz \& Østrup, 1899; Jessen \& Milthers, 1928; Andersen, $1965 ; 1966)$. The site is particularly famous for its pollen record, which covers the whole vegetation succession of the interglacial including the presence of relatively warm demanding species such as Hedera helix and Ilex aquifolium. Previous attempts to date the interglacial sediments from Hollerup include thermoluminescene dating (Kronborg \& Mejdahl, 1989), and an age of $88 \mathrm{ky}$ was obtained from the diatomite in pollenzone 6 (Fig. 3). This age is not corrected for 'shallow traps' and using the correction in Mejdahl \& Funder (1994) a depositional age of the diatomite of $120 \mathrm{ky}$ can be calculated, however, without no clear indication of the errors.

Previous attempts to date lake sediments with the
${ }^{238} \mathrm{U}-{ }^{230} \mathrm{Th}$ method have concentrated on carbonate-rich sediments (Latham and Schwarcz, 1992; Lin et al., 1996) or a combination of carbonate- and organic-rich sediments (Israelson et al., 1997). Problems with dating of carbonate-rich sediments include postdepositional migration of $U$ and correction for initial ${ }^{230} \mathrm{Th}$. Peat deposits have been successfully dated and reliable ages from interglacial deposits $(\sim 125 \mathrm{ky})$ have been obtained although it was often found that peat shows open system behaviour (Vogel \& Kronfeld, 1980; Heijnis and van der Plicht, 1992; Heijnis et al., 1993).

The sediments at Hollerup include both very carbonate-rich, and carbonate-poor but organic-rich sediments. They therefore provide a unique opportunity to test U-series systematics in both organic and carbonate sediments which should have experienced the same diagenetic history. 


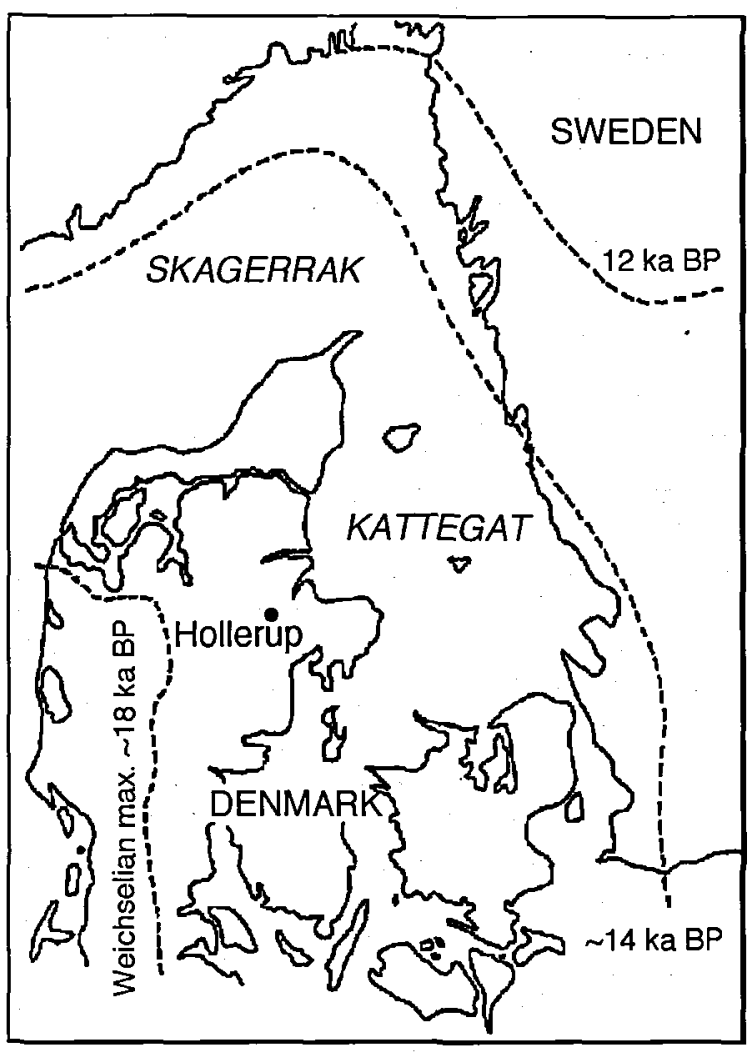

Figure 1. Denmark and the location of Hollerup interglacial lake deposits. The dotted lines are the pattern of the last deglaciation in southern Scandinavia (Lagerlund \& Houmark-Nielsen, 1993).

\section{Methods}

Between 0.4 and $1.5 \mathrm{~g}$ of sediment was totally dissolved in a mixture of $\mathrm{HNO}_{3}-\mathrm{HF}-\mathrm{HClO}_{4}$ acids and spiked with a mixed ${ }^{229} \mathrm{Th}-{ }^{236} \mathrm{U}$ tracer before $\mathrm{U}$ and $\mathrm{Th}$ were separated using anion exchange columns. $U$ and $T h$ isotopes and concentrations were determined with thermal ionization mass spectrometry (TIMS) at The Open University following methods described previously (van Calsteren \& Schwieters, 1995; Israelson et al., 1997). All isotope values were converted into activity ratios using the decay constants from Ivanovich et al. (1992) (round brackets on ratios signify an activity ratio).

Samples with high Th contents and $\left({ }^{230} \mathrm{Th} /{ }^{232} \mathrm{Th}\right)$ ratios less than 2 were analysed in static mode on double $\operatorname{Re}$ filaments, and samples with lower $\mathrm{Th}$ content and more radiogenic $\left({ }^{230} \mathrm{Th} /{ }^{32} \mathrm{Th}\right.$ ) values were analysed on single Re filaments in dynamic single collector mode.

The total carbon contents (TC) were measured in a Metalyt 90S furnace and the $\mathrm{CaCO}_{3}$ contents were determined by titration. The total organic content (TOC) was calculated as TOC $=\mathrm{TC}-\left(\mathrm{CaCO}_{3} \times 12 /\right.$
100); organic matter was calculated as TOCx 2.5 , and the residue is that left after subtraction of the organic matter and $\mathrm{CaCO}_{3}$. All the values are plotted as percentages of the dry weight (Fig. 3).

\section{Results \\ Lithostratigraphy}

The sediment sequence analyzed by Andersen (1965) .was more than $8 \mathrm{~m}$ thick and comprised a combination of an open section and a coring in a more central part of the former lake basin. He distinguished five different types of sediments (from bottom to top): sand, lake marl, calcareous gyttja, diatom gyttja and clay gyttja. The section that is now available is situated closer to the former lake shore and has possibly been subject to a more discontinuous sedimentation (Fig. 2). However, the general lithostratigraphy as well as variation in carbonate and organic matter are very similar to Andersen's (1966) (Fig. 3), which enables a fairly good correlation to his profile from where the complete pollen diagram has been established. We have thus added the pollen zonation on Figure 3 based on this correlation.

\section{$\mathrm{U}$ and Th measurements}

The results of the $U$ and Th measurements are shown in Table 1 and Figure 3 together with content of organic matter and carbonate. The residual non-carbonate or organic matter consists of silicious diatomite material and clay, between 2 and 80 percent, and is highest in the upper part of the section. Based on the carbonate content the section can be roughly divided into two parts. The lower part between 385 and $155 \mathrm{~cm}$ which contains up to $95 \%$ carbonate, and the upper part between 155 and $0 \mathrm{~cm}$ which hardly contains any carbonates at all.

Uranium contents vary between 0.067 and $1.43 \mathrm{ppm}$ with the lowest values in the lowermost carbonaterich sediments and the highest in the organic-rich sediments in the upper part of the section. There is a clear positive correlation between $U$ content and the amount of organic matter with the highest $U$ contents in organic-rich levels (Fig. 4), although the samples with very low $U$ and organic content fall slightly off this trend. The ${ }^{232}$ Th content increases when the carbonate and organic content decreases (increasing amounts of siliceous residue) and the highest concentrations of ${ }^{232} \mathrm{Th}$ are in the upper levels (Fig. 3).

All samples show disequilibrium both with respect to $\left({ }^{234} \mathrm{U} /{ }^{238} \mathrm{U}\right.$ ) and $\left({ }^{230} \mathrm{Th} /{ }^{238} \mathrm{U}\right)$ ratios (Fig. 3). There is, however, an obvious pattern as to which samples have activity ratios above and below unity. The samples from the carbonate-present part of the sediments have $\left.{ }^{230} \mathrm{Th} /{ }^{238} \mathrm{U}\right)$ ratios higher than 1 and all but one sam- 
Figure 2. Sedimentary log of the interglacial lake sediment from Hollerup between 60 and $320 \mathrm{~cm}$ below the Weichselian sandlayers.

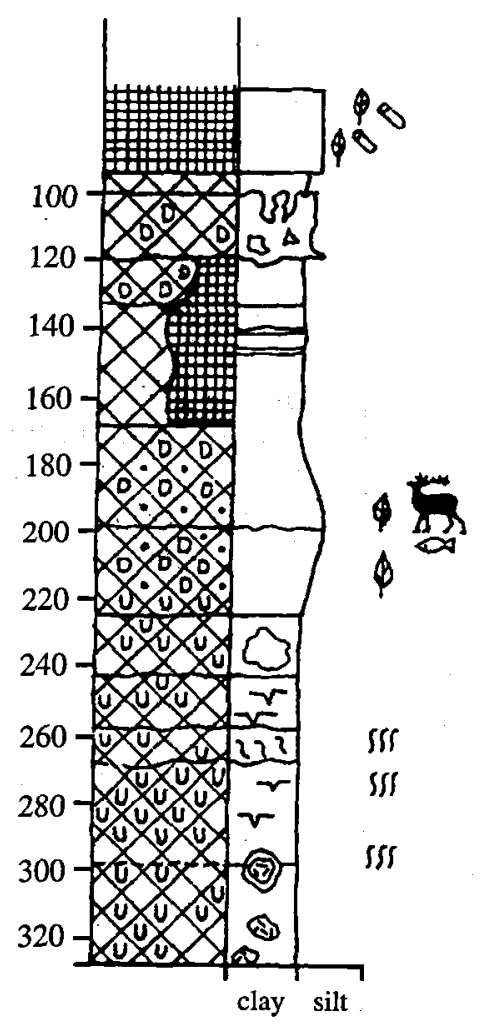

Massive diatomite with many

macro plant fossils

Sharp very irregular boundary

with sediment infill and chemical reaction boundary

Two light bands

Increasing organic matter, macro

fossils, fish bones and scales, Fallow deer

Indistinct dark grey spots, $6-10 \mathrm{~cm}$ thick

Indistinct borrows

Mottled with white spots

Increasing organic content, dark greenish.

White spots $2-4 \mathrm{~cm}$ with dark rims

Irregular black spots with visible organic debris.

Calcareous gyttja. Organic matter increase upwards

UXV calcareous gyttja
diatomite
$\therefore \therefore$ sand
$\square$ indistinct transition
$\ldots$ gradual transition

sss bioturbation

$\$$ leaves, macro plant fossils

small twigs

$\propto$ fishbones and scales

Fallow deer ple from the organic-rich part of the sediment, where the carbonate contents are less than the detection limit, have ratios lower than 1 (Table 1).

Figure 5 shows the $\left({ }^{234} \mathrm{U} /{ }^{232} \mathrm{Th}\right)$ vs. $\left({ }^{238} \mathrm{U} /{ }^{232} \mathrm{Th}\right)$. This plot indicates if there is a mixing between two or more uranium components. It is possible to draw two best fit lines, one through the samples from the carbonateabsent part of the sediments and one through the samples from the carbonate-present part of the sediments. It is seen from Figure 5 that both trends have a clear positive correlation which indicates that the samples are dominated by two $\mathrm{U}$ components with different $\left({ }^{234} \mathrm{U} /{ }^{238} \mathrm{U}\right)$ values.

\section{Discussion}

We know that the sediments at Hollerup were deposited during the last interglacial, the Eemian (Jessen \& Milthers, 1928; Andersen, 1965). The chronology of the last interglacial is not well established but ${ }^{238} \mathrm{U} /$ ${ }^{230}$ Th dating of corals and marine sediments has placed the marine oxygen iso-tope stage $5 \mathrm{e}$, which corresponds to the relatively warm interglacial Eemian, somewhere between 117 and 135 ky (Hamelin et al., 1991; Stirling et al., 1995; Bard et al., 1996; Slowey et al., 1996). Therefore we assume, based on the warm demanding pollen species, that the major part of the lake sediments from Hollerup were deposited somewhere in this interval. 


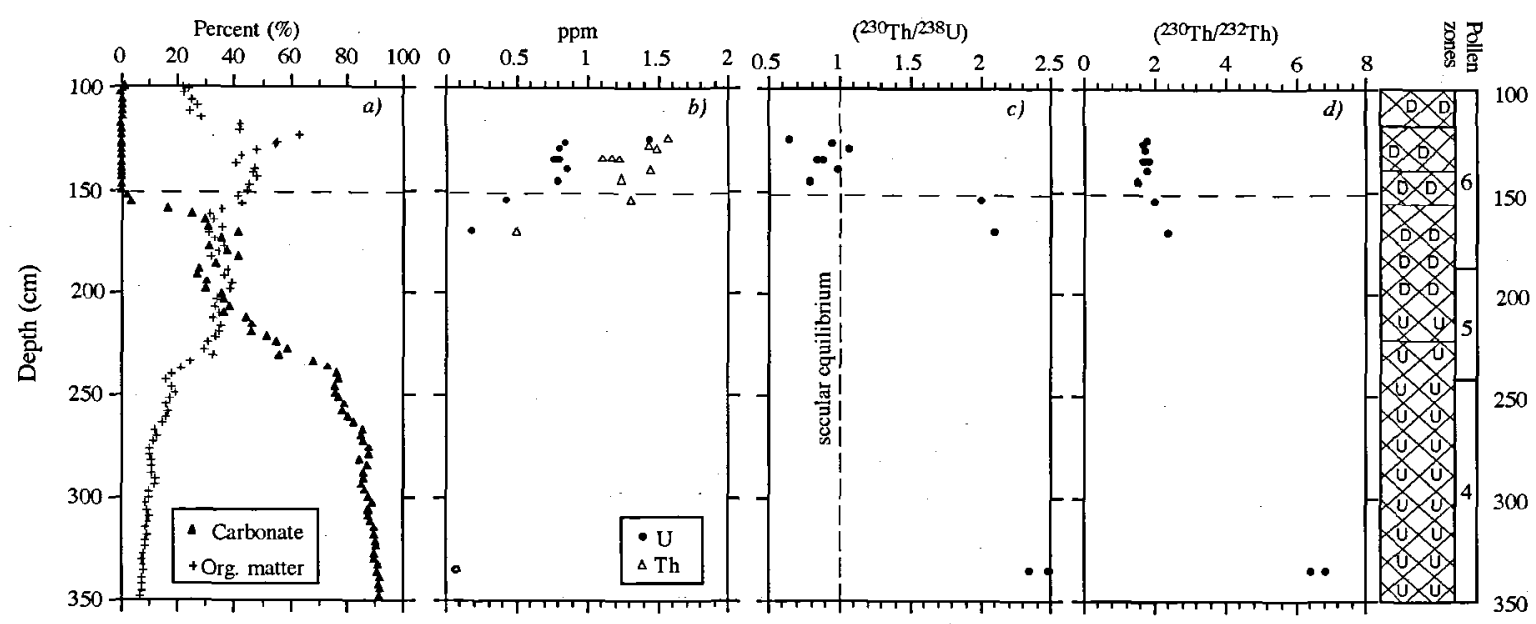

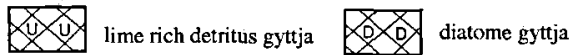

Figure 3. a) Percent carbonate and organic matter, b) $U$ and Th concentrations, c) $\left({ }^{230} \mathrm{Th} /{ }^{238} \mathrm{U}\right)$ ratios, where the vertical dotted line indicates secular isotopic equilibrium between ${ }^{230} \mathrm{Th}$ and ${ }^{238} \mathrm{U}\left(\left({ }^{230} \mathrm{Th} /{ }^{238} \mathrm{U}\right)=1\right)$; d) $\left({ }^{230} \mathrm{Th} /{ }^{332} \mathrm{Th}\right)$ ratios from the sediments at the interglacial lake deposits from Hollerup. The horisontal dotted line indicates the limit between carbonate-present (below) and carbonate-absent (above) samples. The pollen zones are from Andersen (1966). The correlation between Andersen's and our section is based on the lithology and the carbonate content.

In general, the samples analysed in this study fall in two groups: those with $\left({ }^{230} \mathrm{Th} /{ }^{38} \mathrm{U}\right)$ values higher than 1 , and those with values less than 1 . Given that ${ }^{230} \mathrm{Th}$ is a decay product of ${ }^{238} \mathrm{U},\left({ }^{230} \mathrm{Th} /{ }^{238} \mathrm{U}\right)$ ratios higher than 1 must reflect later leaching of $U$ or addition of Th from the sediments. Addition of Th is not likely since $T h$ is much less soluble than $U$ and is effectively immobile in groundwater (Osmond \& Cowart, 1992). In Table 1, it is seen that the five samples that have experienced late $U$ leaching, with the exception of sample $130 \mathrm{~cm}$, are from the carbonate-present part of the section (samples 335a and b, 130, 155 and 170 $\mathrm{cm})$. This indicates that the carbonate hosted $U$ has been more readily mobilized, probably by percolation of groundwater, than the $U$ originally contained in the organic and clastic sedimentary material. The relatively radiogenic $\left({ }^{230} \mathrm{Th} /{ }^{232} \mathrm{Th}\right)$ values, $\sim 6.5$, in samples $335 \mathrm{a}$ and $335 \mathrm{~b}$, suggest that the sediments originally had a higher $U$ content and that they did remain closed with respect to $U$ for a significant time after deposition.

Samples with $\left({ }^{230} \mathrm{Th} /{ }^{238} \mathrm{U}\right)$ values less than 1 can be interpreted in two ways. 1) The sediment remained closed with respect to $U$ and its decay products since deposition and an age can be calculated from the

Table 1. $\mathrm{U}$ and Th concentrations and isotopic compositions in interglacial lake deposits from Hollerup. 'TOC' is total organic carbon. Samples marked with small letters (a to d) are duplicates. Model ages are calculated without correction for detrital Th.

\begin{tabular}{|c|c|c|c|c|c|c|c|c|c|}
\hline Sample & $\begin{array}{l}\text { Depth } \\
\text { (cm) }\end{array}$ & $\begin{array}{l}\text { Carbonate } \\
(\%)\end{array}$ & $\begin{array}{l}\text { TOC } \\
(\%)\end{array}$ & $\begin{array}{l}{ }^{238} \mathrm{U} \\
\text { (ppm) }\end{array}$ & $\begin{array}{l}{ }^{232} \mathrm{Th} \\
\text { (ppb) }\end{array}$ & $\begin{array}{l}\left({ }^{234} U /{ }^{238} U\right) \\
\pm 2 \sigma\end{array}$ & $\begin{array}{l}\left({ }^{230} \mathrm{Th} /{ }^{232} \mathrm{Th}\right) \\
\pm 2 \sigma\end{array}$ & $\left({ }^{230} \mathrm{Th} /{ }^{238} \mathrm{U}\right)$ & $\begin{array}{l}\text { 'model' } \\
\text { ages (ky) }\end{array}$ \\
\hline Ho125b & 125 & 0 & 25.2 & 1.434 & 1577 & $1.1454 \pm 58$ & 1.817 & $0.6531 \pm 29$ & 90 \\
\hline Ho127 & 127 & 0 & 22.0 & 0.844 & 1435 & $-1.1305 \pm 75$ & 1.698 & $0.9442 \pm 56$ & 183 \\
\hline Ho 130 & 130 & 0 & 19.2 & 0.810 & 1497 & $1.1393 \pm 80$ & 1.771 & $1.0705 \pm 67$ & - \\
\hline Ho135 & 135 & 0 & 16.8 & 0.801 & 1172 & $1.1592 \pm 105$ & 1.768 & $0.8453 \pm 115$ & 136 \\
\hline Ho135d & 135 & 0 & 16.8 & 0.797 & 1227 & $1.1506 \pm 40$ & 1.682 & $0.8467 \pm 27$ & 136 \\
\hline Ho135b & 135 & 0 & 16.8 & 0.764 & 1115 & $1.1555 \pm 122$ & 1.841 & $0.8788 \pm 82$ & 147 \\
\hline Hol40 & 140 & 0 & 18.8 & 0.862 & 1436 & $1.1439 \pm 123$ & 1.815 & $0.9891 \pm 93$ & 199 \\
\hline Ho145 & 145 & 0 & 18.9 & 0.791 & 1241 & $1.1506 \pm 47$ & 1.553 & $0.7969 \pm 135$ & 123 \\
\hline Ho155 & 155 & 3 & 17.0 & 0.428 & 1309 & $1.1458 \pm 87$ & 2.000 & $2.003 \pm 182$ & - \\
\hline Ho 170 & 170 & 41 & 12.4 & 0.190 & 505 & $1.1819 \pm 83$ & 2.403 & $2.091 \pm 35$ & - \\
\hline Ho335a & 335 & 91 & 3.2 & 0.085 & 89 & $1.4197 \pm 47$ & 6.860 & $2.349 \pm 14$ & - \\
\hline Ho335b & 335 & 91 & 3.2 & 0.066 & 78 & $1.4384 \pm 64$ & 6.459 & $2.488 \pm 80$ & - \\
\hline
\end{tabular}




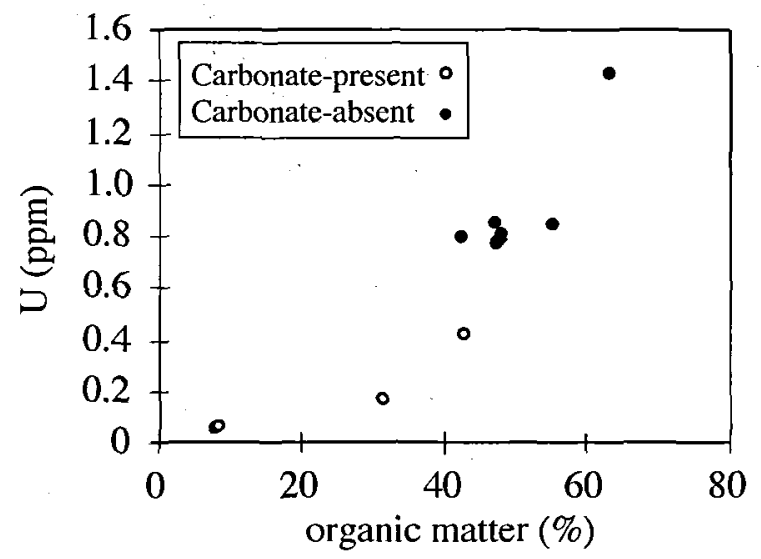

Figure 4. Uranium content vs. percent organic matter in the lake sediments.

${ }^{(230} \mathrm{Th} /{ }^{238} \mathrm{U}$ ) and $\left({ }^{234} \mathrm{U} /{ }^{238} \mathrm{U}\right)$ ratios (after possible correction for initial Th and U) (Ivanovich et al., 1992). 2) The samples have experienced a much more complex post depositional history involving one or several episodes of leaching and absorption of $U$.

If we uncritically calculate ages from $\left({ }^{230} \mathrm{Th} /{ }^{38} \mathrm{U}\right)$ and $\left({ }^{234} \mathrm{U} /{ }^{238} \mathrm{U}\right)$ ratios of all the Hollerup samples with $\left({ }^{230} \mathrm{Th} /{ }^{238} \mathrm{U}\right)$ values less than one we obtain ages between $89 \mathrm{ky}$ and $199 \mathrm{ky}$ with an average of $144 \mathrm{ky}$ (without correction for initial Th) (Table 1). These ages have been calculated using the age equation originally published by Kaufman \& Broecker (1965). These ages are clearly incorrect since the measured sediments were deposited over a much shorter time interval, probably within less than 3000 years. This estimated time span is based on correlation between our sediment lithology, Andersen's (1965) pollen diagram and lithology, and Müllers (1974) annually laminated pollen sequence at Bispingen.

The U-Th ages were calculated without any correction for detrital $U$ and $T h$ which should make the ages too old. Any attempt to correct for initial Th and $U$ based on the detrital $U$ and $T h$ concentration requires an assumed ${ }^{232} \mathrm{Th} /{ }^{238} \mathrm{U}$ ratio of the detrital component. If we assume secular equilibrium between ${ }^{238} \mathrm{U},{ }^{234} \mathrm{U}$ and ${ }^{230} \mathrm{Th}$ for this detrital component then we can correct the measured $\left({ }^{230} \mathrm{Th} /{ }^{238} \mathrm{U}\right)$ and $\left({ }^{234} \mathrm{U} /{ }^{238} \mathrm{U}\right)$ from the bulk sediment using the present ${ }^{232} \mathrm{Th}$ content of the sediments. A realistic detrital ${ }^{232} \mathrm{Th} /{ }^{238} \mathrm{U}$ ratio is difficult to constrain but Eisenhauer et al. (1993) suggested a value for average continental crust of 3.8. If we use this value to correct for example Sample Ho135b (Table 1) we get an age of 109 ky which is approximately $25 \%$ lower than the uncorrected value (147 ky). A higher detrital ${ }^{232} \mathrm{Th} /{ }^{338} \mathrm{U}$ estimate makes the correction less and if we use $\mathrm{a}^{232} \mathrm{Th} /{ }^{238} \mathrm{U}$ value of 5 instead of 3.8 we obtain an age of $118 \mathrm{ky}(20 \%$ correc-tion). The other model ages can be corrected in a similar way and the percentage of correction will be approximately the same because they have similar ${ }^{232}$ Th concentrations (Table 1). Hence, all ages will be corrected towards lower values but the spread in ages will still be approximately the same as before correction.

The relation between $\left({ }^{234} \mathrm{U} /{ }^{232} \mathrm{Th}\right)$ and $\left({ }^{238} \mathrm{U} /{ }^{232} \mathrm{Th}\right)$ is shown in Figure 4. The linear relation for both the carbonate-present and the carbonate-absent samples suggests a two component mixture of $U$ between an authigenic and a detrital ${ }^{232} \mathrm{Th} /{ }^{238} \mathrm{U}$ component and the
Figure 5. $\left({ }^{234} \mathrm{U} /{ }^{232} \mathrm{Th}\right)$ ys. ${ }^{238} \mathrm{U} /$ ${ }^{232} \mathrm{Th}$ ), regression lines for carbonate-present and carbonate-absent samples are shown.

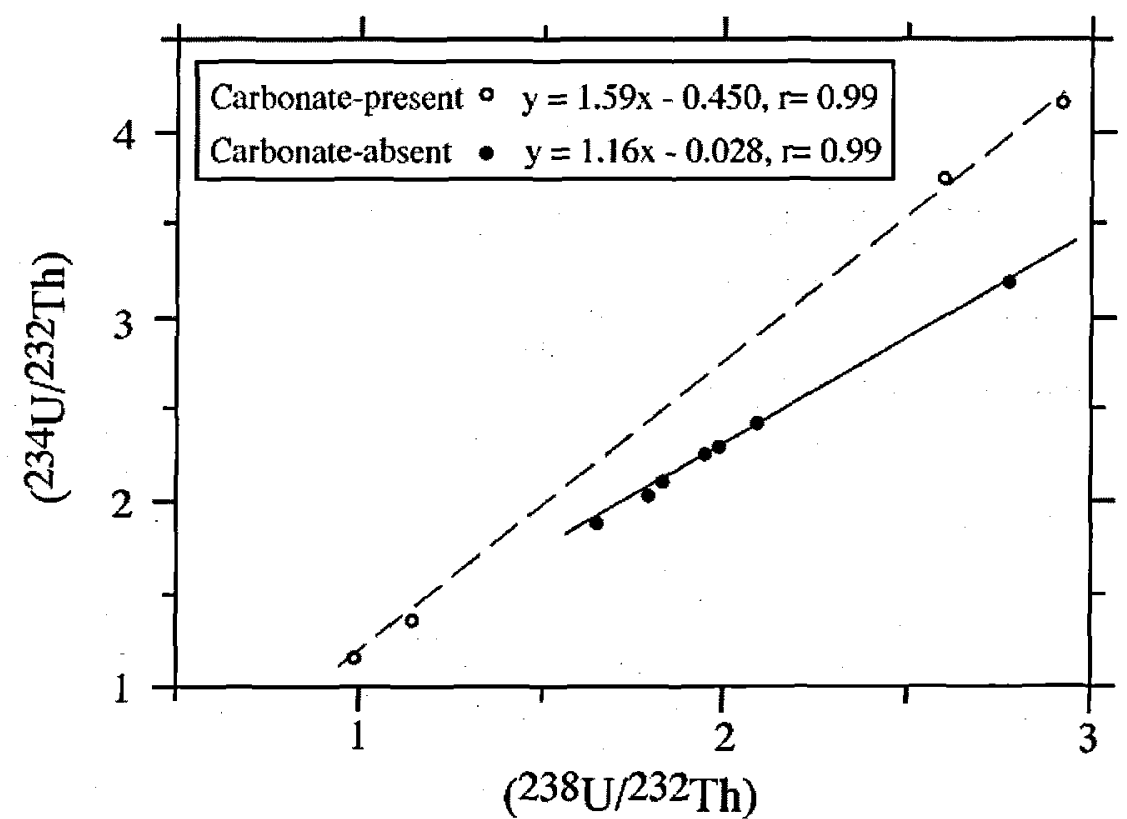


slope of the regression lines defines the $\left({ }^{234} U /{ }^{238} U\right)$ values of the authigenic component (Bischoff \& Fitzpatrick, 1991). The very good fits $(r=0.99)$ for the two regressions indicate that the $\mathrm{U}$ isotopic composition of the authigenic component for both carbonatepresent and the carbonate-absent samples are welldefined and that they have $\left({ }^{234} \mathrm{U} /{ }^{238} \mathrm{U}\right)$ values of 1.59 and 1.16 respectively (Fig. 4). However, the authigenic $U$ component can not be original since the samples then would have the same U-Th age. The organic-rich sediments (between 125 and $150 \mathrm{~cm}$ depth) were therefore probably influenced by several episodes of $U$ migrations involving addition of $U$ to some intervals and leaching of $\mathrm{U}$ from others.

\section{Conclusions}

We have analysed the $U$ and $T h$ isotopic compositions of sediments from the interglacial lake sediments from Hollerup, Denmark. It was found that all samples are affected by post deposition mobilization of $U$ and it is not possible to calculate accurate U-Th ages.

Carbonate-rich sediments are strongly affected by leaching of $U$ and probably have only a fraction of their original $U$ content. Sediments consisting of mostly organic matter and detrital material have a more complex diagenetic history, probably involving several episodes of U leaching and absorption. However, UTh isotopic composition of most samples are in agreement with a last interglacial depositional age (135$117 \mathrm{ky})$.

A previous study of Holocene sediments from Lake Igelsjön, southern Sweden, has shown that carbonaterich algae gyttja can have a very high $U$ content and that this sediment type is extremely suitable for dating with the U-Th technique (Israelson et al., 1997). Originally, the carbonate-rich sediments from Hollerup were probably comparable to the sediments from Lake Igelsjön but compaction and groundwater seepage have subsequently affected the $U$ and $T h$ content and isotopic compositon of the sediments which makes it impossible to obtain precise ages. Future attempts to date ancient lake sediments with the U-Th method should concentrate on sediments that have remained deeply buried and thus not affected by oxidized ground waters which tend to mobilize U.

\section{Dansk sammendrag}

Vi har analyseret uran-serie isotoper fra interglaciale søsedimenter fra Hollerup, Jylland, for at undersøge muligheden for at datere disse og lignende sedimenter med U-Th dateringsmetoden. Sedimenterne fra Hollerup kan deles op i 2 grupper: En gruppe med højt indhold af karbonat og en anden helt uden karbonat, der består af organisk materiale, ler og kieselalger.
Alle sedimenter med højt karbonatindhold (40-95\%) har $\left({ }^{230} \mathrm{Th} /{ }^{238} \mathrm{U}\right)$ forhold højere end 1, hvilket tyder på udvaskning af uran, formentlig af grundvand, efter aflejring. Sedimenter med højere indhold af organisk materiale, men uden karbonat har $\left({ }^{230} \mathrm{Th} /{ }^{238} \mathrm{U}\right)$ forhold mindre end $1 \mathrm{og}$ 'modelaldre' mellem 89 og 199 tusind år kan udregnes. Den store spredning $\mathrm{i}$ beregnede aldre af sedimenter, der er aflejret over et meget mindre tidsinterval (højst et par tusinder år) tyder på en indviklet post-aflejringshistorie, der sandsynligvis har indvolveret flere episoder af udvaskning og absorbering af uran fra grundvand. Det har tidligere været muligt at datere holocæne sedimenter fra Igelsjön i det sydlige Sverige meget lig sedimenterne fra den karbonatholdige del af Hollerup profilet (Fig. 2). Hollerup sedimenterne er imidlertid så påvirkede af kompaktion og grundvandsgennemstrømning at en pracis datering med U-Th metoden ikke er muligt.

\section{Acknowledgement}

For help with the analytical work and field work we thank Mabs Gilmoure, Peter van Calsteren and Torben Fronval. Formal reviews by K. L. Knudsen and D. W. Peate improved the manuscript. This research was supported by grants from The Carlsberg Foundation to C.I., from Danish Natural Science Research Council (CATLINA-project) to C.I., S.B. and N.N.N. and by NERC to C.J.H.

\section{References}

Andersen, S. T., 1965: Interglacialer og interstiadialer $\mathrm{i}$ Danmarks kvartær. Meddelelser fra Dansk Geologisk Forening 15, 486-506.

Andersen, S. T., 1966: Interglacial vegetational succession and lakke development in Denmark. The Palaeobotanist $15,117-127$.

Bard, E., Jouannic, C., Hamelin, B., Pirazzoli, P., Arnold, M., Faure, G., Sumosusastro, P., Syaefudin, 1996: Pleistocene sea level and tectonic uplift based on dating of corals from Sumba Island, Indonesia. Geophysical Research Letters 23, 1473-1476.

Bischoff, J. L. \& Fitzpatrick, J. A., 1991: U-series dating of impure carbonates: An isochron technique using totalsample dissolution. Geochimica et Cosmochimica Acta 55, 543-554.

Eisenhauer, A., Wasserburg, G. J., Chen, J. H., Bonani, G., Collins, L. B., Zhu, Z. R. \& Wyrwoll, K. H., 1993: Holocene sea-level determination relative to the Australian continent: U/Th (TIMS) and ${ }^{14} \mathrm{C}$ (AMS) dating of coral cores from the Abrolhos Islands. Earth and Planetary Science Letters 114, 529-547.

Hamelin, B., Bard, E., Zindler, A. \& Fairbanks, R. G., 1991: ${ }^{234} \mathrm{U} /{ }^{238} \mathrm{U}$ mass spectrometry of corals: How accurate is the U-Th age of the last interglacial period? Earth and Planetary Science Letters 106, 169-180.

Hartz, N. \& Østrup, E., 1899: Danske Diatoméjordaflejringer og deres Diatoméer. Danmarks Geologiske Undersøgelse, II. Række, Nr. 9, 81 pp. 
Heijnis, H. \& van der Plicht, J., 1992: Uranium/thorium dating of Late Pleistocene peat deposits in NW Europe, uranium/thorium isotope systematics and open-system behaviour of peat layers. Chemical Geology 94, 16i171.

Heijnis, J., Ruddock, J. \& Coxon, P., 1993: A uranium-thorium dated late Eemian or early Midlandian organic deposit from near Kelfenora between Spa and Fenit, Co. Kerry, Ireland. Journal of Quaternary Science 8, 31-43.

Israelson, C., Björck, S., Hawkesworth, C. J., Possnert, G., 1997: Direct U-Th dating of organic- and carbonate-rich lake sediments from southern Scandinavia. Earth and Planetary Science Letters 153, 251-263.

Ivanovich, M., Latham, A. G. \& Ku, T. L. 1992: Uraniumseries disequilibrium applications in geochronology. In M. Ivanovich \& R. S. Harmon (eds) Uranium-series disequilibrium, 62-94.

Jessen, K. \& Milthers, V., 1928: Stratigraphical and paleontological studies of interglacial fresh-water deposits in Jutland and Northwest Germany. Danmarks Geologiske Unders $\emptyset$ gelse, II. Rakke, Nr. 48, 380 pp.

Kaufman, A. \& Broecker, W. S. 1965: Comparison of ${ }^{230} \mathrm{Th}$ and ${ }^{14} \mathrm{C}$ ages for carbonate materials from Lake Lahontan and Bonneville. Journal of Geophysical Research 96, 4039-4054.

Kronborg, C. \& Mejdahl, V. 1989: Thermoluminescence dating of Eemian and early Wechselian deposits in Denmark. Quaternary International 3/4, 93-99.

Lagerlund, E. \& Houmark-Nielsen, M. 1993: Timing and pattern of the last deglaciation in the Kattegat region, southwest Scandinavia. Boreas 22, 337-347.

Latham, A. G. \& Schwarcz, H. P., 1992: Carbonate and sulphate precipitates. In M. Ivanovich \& R. S. Harmon (eds) Uranium-series disequillibrium, 423-459.

Lin, J. C., Broecker, W. S., Anderson, R. F., Rubenstone, J. L., Hemming, S. \& Bonani, G., 1996: New ${ }^{230} \mathrm{Th} / \mathrm{U}$ and ages ${ }^{14} \mathrm{C}$ ages from Lake Lahontan (Nevada) carbonates and implications for the origin of their initial Th contents. Geochimica et Cosmochimica Acta 60, 2817-2832.

Mejdahl, V.\& Funder, S. 1994: Luminescence dating of Late Quaternary sediments from East Greenland. Boreas 23, 525-535.

Müller, H. 1974: Pollenanalytische untersuchungen und jahresschichtenzählungen an der eem-zeitlichen kieselgur von Bispingen/Luhe. Geologisches Jahrbuch 21, 149-169.

Osmond, J. K. \& Cowart, J. B., 1992: Ground water. In M. Ivanovich \& R. S. Harmon (eds) Uranium-series disequilibrium, 290-333.

Slowey, B. C., Henderson, G. M., \& Curry, W. B., 1996: Direct U-Th dating of marine sediments from the two most recent interglacial periods. Nature 383, 242-243.

Stirling, C. H., Esat, T. M., McCulloch, M. T. \& Lambeck, K., 1995: High Precision U-series dating of corals from Western Australia and implications for the timing and duration of the Last Interglacial. Earth and Planetary Science Letters $135,115-130$.

van Calsteren, P. \& Schwieters, J. B., 1995: Performance of a thermal ionisation mass spectrometer with a deceleration lens system and post-deceleration detector selection. International Journal of Mass Spectrometry and Ion Processes 146/147, 119-129.

Vogel, J. C. \& Kronfeld, J., 1980: A new method for dating peat. South African Journal of Science 76, 557-558. 